\title{
A Review on Role of Arecoline and Its Metabolites in the Molecular Pathogenesis of Oral Lesions with an Insight into Current Status of Its Metabolomics
}

\section{Aparajita Das, Sarbani Giri}

Laboratory of Molecular and Cell Biology, Department of Life Science and Bioinformatics, Assam University, Silchar, India

Received June 5, 2018; Accepted November 9, 2020.

Key words: Arecoline - Molecular pathogenesis - Metabolism of arecoline Arecoline $\mathrm{N}$-oxide - Oral submucous fibrosis - Oral cancer

\begin{abstract}
Areca nut consumption is a popular habit in Southeast Asian countries. One of the important biologically active alkaloids of areca nut is arecoline, which plays a role in mediating the development of several pathologies of the primary exposure site, the oral cavity. Studies on the metabolism of arecoline revealed the formation of several metabolites which themselves might be toxic. Moreover, polymorphisms in genes encoding enzymes involved in the metabolism of arecoline might predispose an organism towards the development of oral cancer. The present review tries to accumulate all the relevant existing literature and then elucidate the molecular mechanism by which arecoline plays a role in the development of oral submucous fibrosis and oral cancer. Existing information regarding arecoline metabolism, enzymes involved in the metabolic process and biological effects of the metabolites of arecoline have also been compiled and compared to study the toxicity of metabolites with its parent compound arecoline and whether they play any role in the pathogenesis of oral cancer mediated by areca nut consumption. A repertoire of molecular targets has come up in the discussion whose expression profile is perturbed by arecoline. Construction of induction cascade from existing literature has given an idea about the process of molecular pathogenesis. The summarized and analysed data can help to determine the molecular mechanism and drug targets,
\end{abstract}

This study was supported by the University Grants Commission (UGC), India, under UGC Junior Research Fellowship scheme.

Mailing Address: Prof. Sarbani Giri, PhD., Laboratory of Molecular and Cell Biology, Department of Life Science and Bioinformatics, Assam University, Silchar 788011, Assam, India; Phone +91 38422404 00; Fax: +91 38422708 06;

e-mail: girisarbani@gmail.com 
which in turn could be helpful in the prevention or treatment of these pathological conditions. It also brings into light areas where further research needs to be directed.

\section{Introduction}

Mortality is a severe issue in the case of oral cancer, as indicated by the International Agency for Research in Cancer (IARC) report, GLOBOCAN series, 2012. According to this data, globally, 300,000 cases of oral cancer and 145,000 cases of death were reported in the year 2012 (Ferlay et al., 2015). As this form of cancer majorly develops from the squamous cell region of the oral cavity, it is also called oral squamous cell carcinoma (OSCC) (Rivera, 2015). The metastatic form is preceded by several pre-malignant stages, including leukoplakia, erythroplakia, oral lichen planus, and oral submucous fibrosis (OSF). These lesions show different rates of transformation to the cancerous stage: 3.6 to $17.5 \%$ in leukoplakia, $70.3 \%$ in proliferative verrucous leukoplakia, 14 to $50 \%$ in erythroplakia, 0.04 to $1.74 \%$ in oral lichen planus and 7 to $13 \%$ in oral submucous fibrosis (Reichart and Philipsen, 2005; Tilakaratne et al., 2006; Kademani, 2007).

Areca nuts have been classified as a Class I carcinogen by IARC (IARC Working Group on the Evaluation of Carcinogenic Risks to Humans, 2004). The chemical composition of areca nut comprises alkaloids, flavonoids, tannins, along with carbohydrates, proteins, fats, crude fibre, and elements (IARC Working Group on the Evaluation of Carcinogenic Risks to Humans, 2004; Peng et al., 2015). Of these, an important constituent is the alkaloid arecoline (IARC Working Group on the Evaluation of Carcinogenic Risks to Humans, 2004). In a study by Cox et al. (2010), most of the habitual areca nut consumers were found to have a baseline concentration of arecoline in saliva reaching up to $2.4 \mu \mathrm{g} / \mathrm{ml}(0.01 \mathrm{mM})$. Apart from saliva, arecoline was detected in blood plasma, hair samples and breast milk samples from areca nut consumers (Marchei et al., 2005; Pellegrini et al., 2007; Wu et al., 2010). It was also detected in the excreta collected from new-borns, whose mothers had consumed areca nut during their gestation period (Pichini et al., 2003). Therefore, the effects induced by arecoline might be due to its stability in the system apart from direct exposure.

The metabolic profile of arecoline has brought into light the existence of several metabolites (Nery, 1971; Giri et al., 2006). Few of these metabolites have been detected in body fluids of areca nut consumers opening up another area of research involved in investigating the role of these metabolites in areca nut mediated oral pathologies.

In this review, we try to (1) create a metabolic map of arecoline from existing literature, (2) discuss the molecular mechanisms and pathways induced by arecoline that are responsible for the development of oral submucous fibrosis (OSF) and oral squamous cell carcinoma (OSCC), (3) describe the biological effects of arecoline metabolites and thereby assess if the metabolites are more toxic than the parent compound itself and play a part in the pathogenesis of OSF and OSCC, and finally 
(4) understand the mechanism of metabolism of arecoline and arecoline $\mathrm{N}$-oxide by gathering knowledge about enzymes involved, which in turn may enable to estimate predisposition of an individual towards the development of oral cancer in areca nut consumers.

\section{Metabolism of arecoline}

The metabolic profile of arecoline might play a role in areca nut mediated pathogenesis of OSF and OSCC. This brings out the need to delve into the depths<smiles>COC(=O)C1=CCCN(C)C1</smiles>

(a)<smiles>CN1CCCC(C(=O)O)C1</smiles>

(e)<smiles>CN1CCC=C(C(=O)NCC(=O)O)C1</smiles>

(i)<smiles>COC(=O)C1C[N+](C)([O-])CCC1SCC(NC(C)=O)C(=O)O</smiles>

(m)<smiles>CN1CCC=C(C(=O)O)C1</smiles>

(b)<smiles>COC(=O)C1CCC[N+](C)(Cl)C1</smiles>

(f)<smiles>CN1CCCC(C(=O)NCC(=O)O)C1</smiles>

(j)<smiles>COC(=O)C1CN(C)CCC1S</smiles>

(n)<smiles>COC(=O)C1=CCCN(N=O)C1</smiles><smiles>COC(=O)C1=CCC[N+](C)([O-])C1</smiles>

(c)<smiles>CN1CCC=C(C=O)C1</smiles>

(g)<smiles>COC(=O)C1CN(C)CCC1SCC(NC(C)=O)C(=O)O</smiles>

(k)<smiles>COC(=O)C1C[N+](C)([O-])CCC1SC</smiles>

(o)<smiles>O=NN1CCCC(C(=O)O)C1</smiles><smiles>O=C(O)c1ccccc1</smiles>

(d)<smiles>CN1CCC=C(C(=O)OC(CO)CO)C1</smiles>

(h)<smiles>CC(=O)NC(CSC1CCN(C)CC1C(=O)O)C(=O)O</smiles>

(I)<smiles>CN(CCC#N)N=O</smiles>

(p)

Figure 1 - Chemical structure of arecoline and metabolites.

(a) arecoline; (b) arecaidine; (c) arecoline $\mathrm{N}$-oxide; (d) arecaidine $\mathrm{N}$-oxide; (e) $\mathrm{N}$-methylnipecotic acid;

(f) 1-methylnipecotic acid 1-oxide methylester; (g) 1-methyl-3,4-dehydropiperidine-3-carboxaldehyde;

(h) arecaidinylglycerol; (i) arecaidinylglycine; (j) N-methylnipecotylglycine; (k) mercapturic acid of arecoline;

(I) mercapturic acid of arecaidine; $(m)$ mercapturic acid of arecoline N-oxide; (n) 4-mercapto-1-methylnipecotic acid methylester; (o) 4-methylmercapto-1-methylnipecotic acid 1-oxide methylester;

(p) 3-methylnitrosaminopropionitrile; (q) 3-methylnitrosaminopropionaldehyde; (r) N-nitrosoguvacoline;

(s) N-nitrosonipecotic acid.

(b, c, d, e, h, i, j, k, l, m, p, q, r-metabolites of arecoline; d, e, h, i, j, I-metabolites of arecaidine;

$a, b, f, g, k, m, n, o-$ metabolites of arecoline $\mathrm{N}$-oxide; $s$ - metabolite of $\mathrm{N}$-nitrosoguvacoline) 


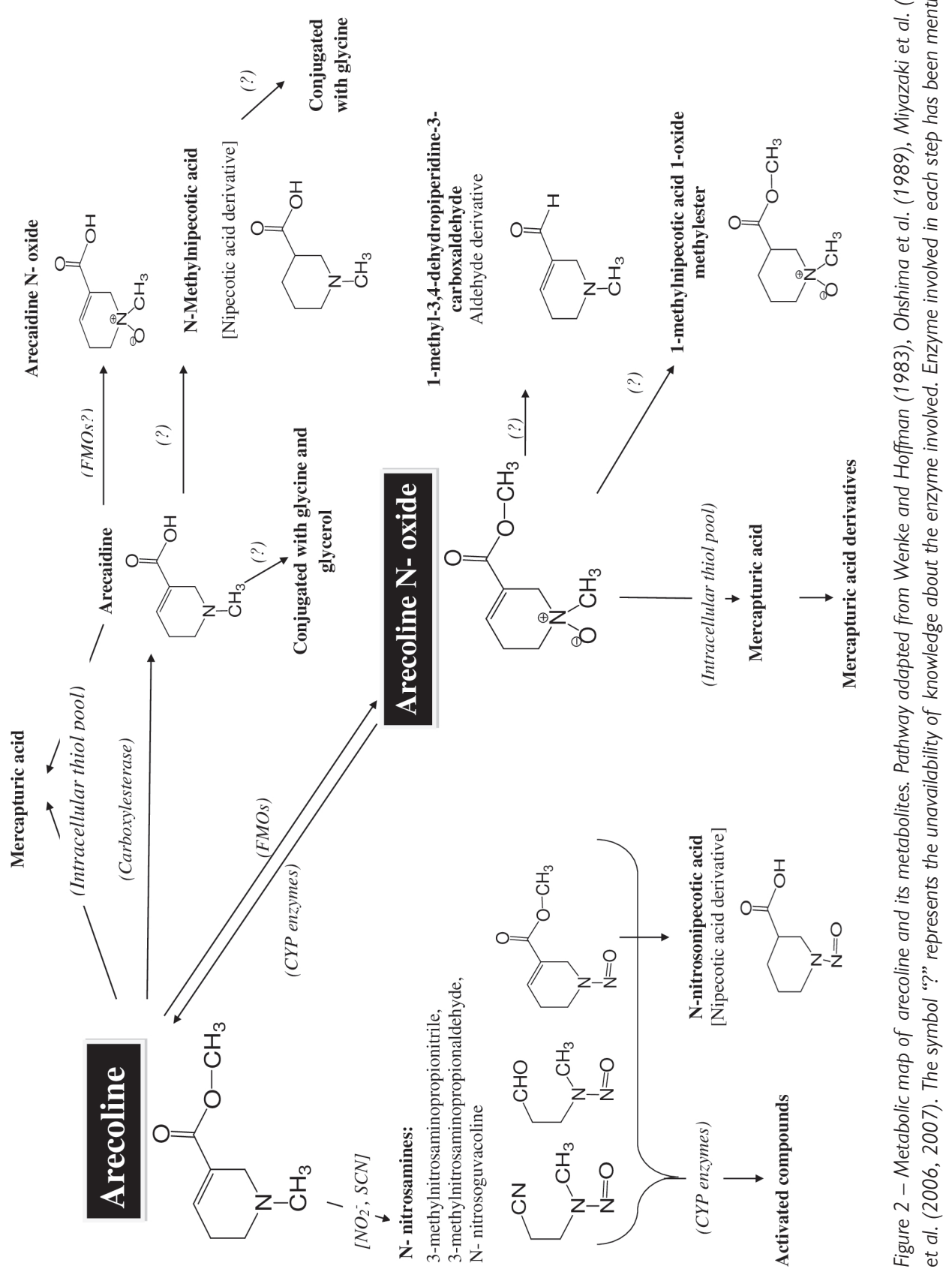


of the metabolomics of arecoline and explore its potential towards the development of oral pathology. Metabolism of arecoline starts in the oral cavity itself. Both nitrite and thiocyanate (catalyst for nitrosation reaction) are present in human saliva (Boyland et al., 1971; Shivapurkar et al., 1980; Wenke et al., 1984a). When arecoline was incubated with sodium nitrite with or without sodium thiocyanate, the formation of three compounds was observed: 3-(methylnitrosamino)propionaldehyde (MNPA), 3-(methylnitrosamino)propionitrile (MNPN) and N-nitrosoguvacoline (NGL) (Wenke and Hoffmann, 1983). Of these, NGL and MNPN were detected in the saliva of betel quid chewers (without tobacco) in the range of $2.2-9.5 \mu \mathrm{g} / \mathrm{I}$ and 0.5-11.4 $\mu \mathrm{g} / \mathrm{I}$, respectively (Wenke et al., 1984a; Prokopczyk et al., 1987). These findings indicate that nitrosation of arecoline does take place in the oral cavity of areca nut consumers, and thereby, buccal cells do get exposed to these nitrosated metabolites on chewing areca nut. In a mammalian test system, $\mathrm{N}$-nitrosonipecotic acid (NNIP) was detected as a product of metabolism of NGL (Ohshima et al., 1989). MNPA has not been detected in saliva samples of areca nut consumers. However, as the formation of MNPA from arecoline takes place under in vitro conditions, fast metabolism of MNPA to its metabolites in vivo might explain this finding. The metabolome of arecoline, arecaidine and arecoline $\mathrm{N}$-oxide in vivo was investigated by Nery (1971) and Giri et al. (2006, 2007). This research revealed several unknown and novel metabolites (Figure 1). Of these, arecaidine and $\mathrm{N}$-methyl nipecotic acid were detected in the urine of areca nut consumers (Hu et al., 2010).

Figure 2 depicts a metabolic map of arecoline.

\section{Role of arecoline in induction of oral pathologies}

Genotoxic effects of arecoline were proved in mice using tests evaluating the formation of chromosomal aberrations and micronucleus (Shirname et al., 1984; Deb and Chatterjee, 1998). At the molecular level, arecoline induces a DNA damage response cascade involving phosphorylation of ataxia-telangiectasia (ATM) kinase and its downstream targets checkpoint kinase 1/2 (Chk1/2), p53 and Nbs1, leading to a $\mathrm{G} 2 / \mathrm{M}$ cell cycle arrest. However, the overall expression of $p 53$ is downregulated by arecoline, which is followed by suppression of $\mathrm{p} 53$ mediated DNA repair activities and expression of its downstream target p $21^{\text {WAF1 }}$ (Tsai et al., 2008). Arecoline has also been found to induce decreased expression of p21 and p27 via a p53 independent process that includes reactive oxygen species (ROS) and activation of mammalian target of rapamycin complex-1 (mTORC1) pathway (Ji et al., 2012). According to ji et al. (2012), down-regulation of these inhibitors of cell cycle might lead to erroneous DNA replication as the cells escape the G1/S checkpoint. Arecoline also disturbs the fluidity of polymerisation-depolymerisation kinetics of $\alpha$-tubulin by favouring their polymerisation. It leads to a disfigurement of the mitotic spindle and an erroneous arrangement of chromosomes, thereby inducing the pro-metaphase cell cycle arrest (Wang et al., 2010). Apart from these alterations, 


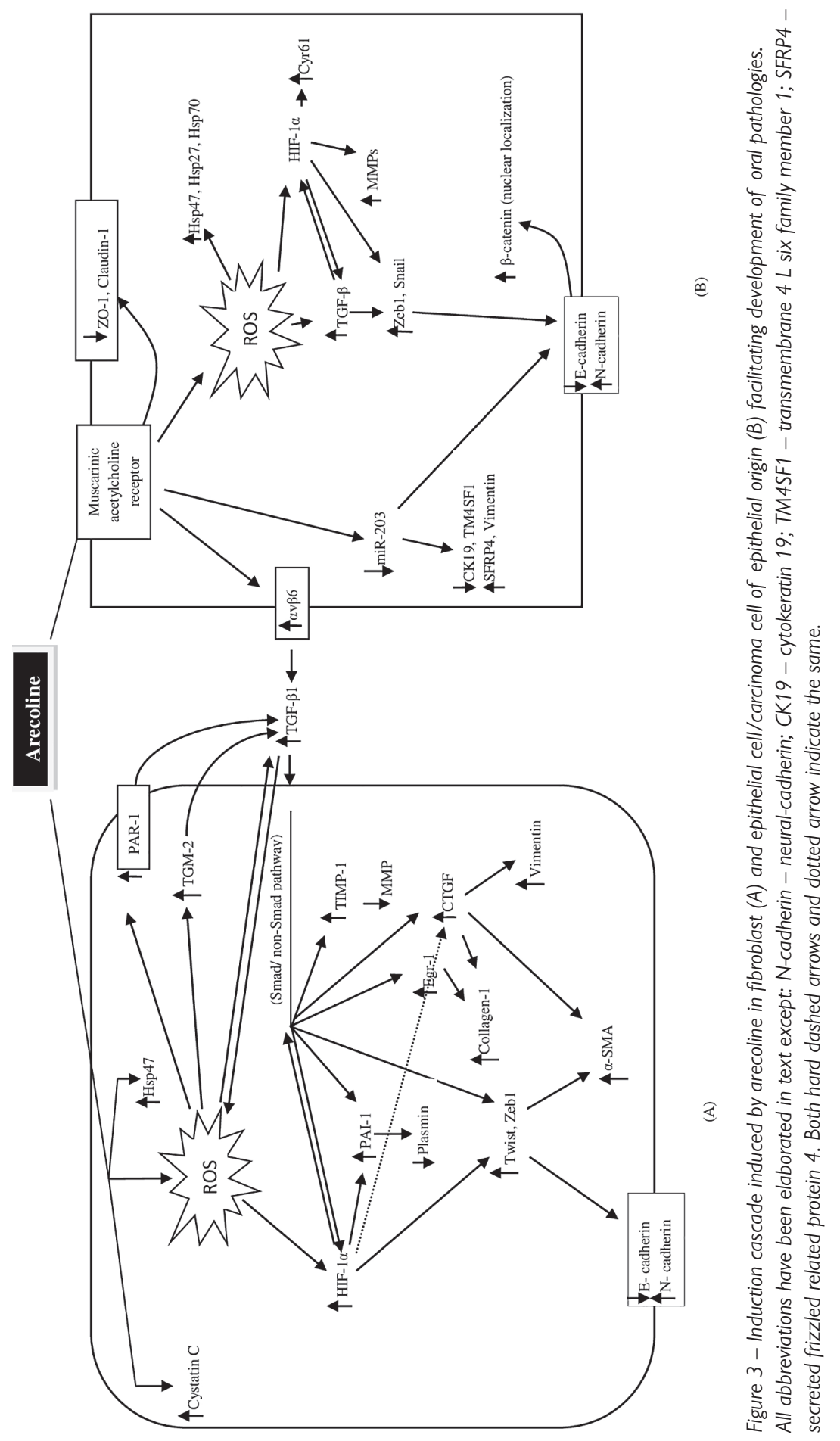

Das A.; Giri S. 
protein expression of several other cell cycle regulatory molecules like cdc $25 c$ in basal carcinoma cells (Huang et al., 2012), cyclin B1 and Wee-1 in KB epithelial cells (Lee et al., 2006) and cyclin D1, cyclin A, cyclin E, CDK4, and CDK2 in HaCaT keratinocytes (Zhou et al., 2013) have been found to be modulated by arecoline.

Arecoline treatment leads to the down-regulation of the immune system in mice (Dasgupta et al., 2006; Wen et al., 2006). By contrast, Hung et al. (2011) reported the production of ROS in endothelial cells on exposure to arecoline, which resulted in an up-regulated expression of adhesion molecules (intercellular adhesion molecule - ICAM, and vascular cell adhesion molecule - VCAM). This effect increased adhesion between mononuclear cells and endothelial cells, which might play a role in augmenting the inflammation. Additionally, several inflammatory cytokines have also been found to be induced by arecoline, such as interleukin-1 $\alpha$, prostaglandin E-2, and cycloxygenase-2 in fibroblasts (Jeng et al., 2003; Tsai et al., 2003; Thangjam and Kondaiah, 2009).

DNA damage and impaired DNA repair, along with chronic inflammation, can be emphasized as the main causes of arecoline induced oral pathologies. Moreover, expression profiles of several extracellular matrix (ECM) proteins, enzymes, growth factors, and transcription factors are altered under the effect of arecoline (Figure 3). All these factors work in an association as indicated by several studies involving fibroblasts, epithelial cells and cancer cell lines (Tables 1 and 2).

Oral submucous fibrosis (OSF) is a pre-cancerous condition that develops from an abnormal wound healing process under continuous exposure to the components of areca nut (Angadi et al., 2011). Inhibition of elements involved in the degradation of extracellular matrix (ECM) or enhanced stability and synthesis of matrix components disturbs the homeostasis of ECM, which can give rise to disease conditions like fibrosis. Arecoline works positively in both these aspects. It enhances the expression of several inhibitors of proteinases, including tissue inhibitors of metalloproteinases (TIMPs), plasminogen activator inhibitors (PAI-1) and cysteine proteinase inhibitor cystatin C in fibroblasts (Chang et al., 2002a; Yang et al., 2003; Tsai et al., 2007) along with induction of factors that enhance the stability of ECM, such as heat shock protein-47 (Hsp-47) and transglutaminase-2 (TGM-2) (Yang et al., 2008; Lee et al., 2015). Moreover, arecoline has been found to decrease the phagocytosis of collagen by fibroblasts (Shieh et al., 2004).

An analysis of the repertoire of moieties affected by arecoline (data compiled in Tables 1 and 2) has bought into light several mediators of the effects induced by arecoline of which three, ROS, transforming growth factor- $\beta 1$ (TGF- $\beta 1$ ) and hypoxia-inducible factor- $1 \alpha$ (HIF-1 $\alpha$ ), might play key roles in the pathogenesis of OSF and OSCC.

Of the several isoforms of TGF- $\beta$ (TGF- $\beta 1 / 2 / 3$ ), TGF- $\beta 1$ is a critical mediator of oral pathologies. Its overexpression has been observed in OSF tissue samples (Kamath et al., 2015). Up-regulated expression of av $\beta 6$ integrin on keratinocytes under arecoline's affect supports the activation of latent TGF- $\beta 1$ present in ECM that 


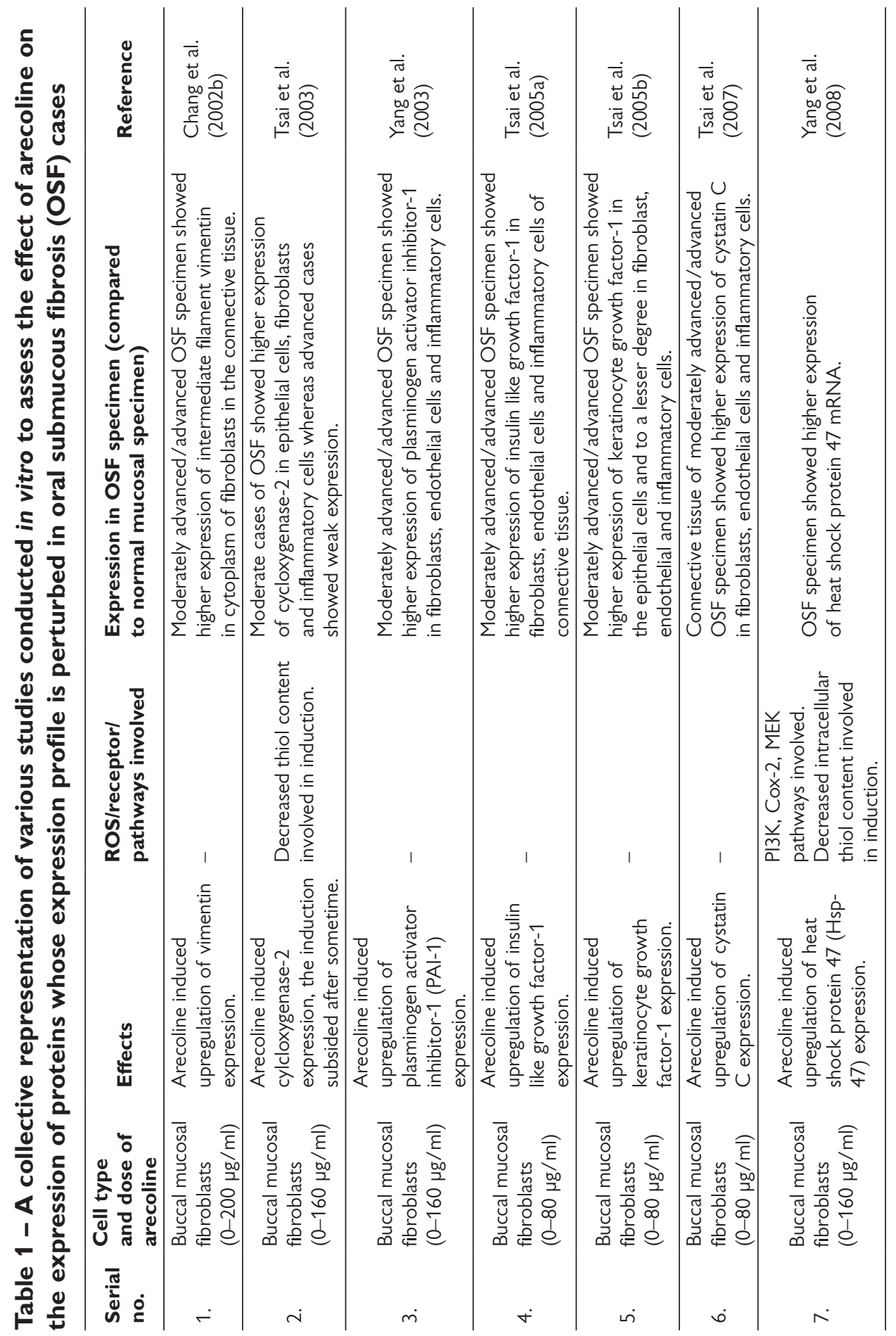




\begin{tabular}{|c|c|c|c|c|c|c|c|}
\hline 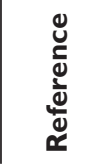 & 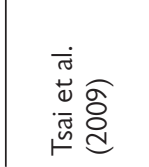 & 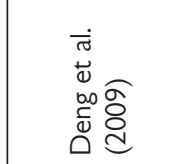 & 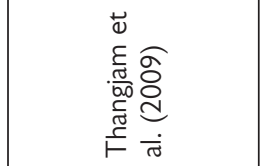 & 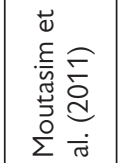 & 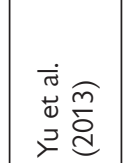 & 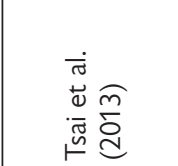 & 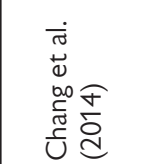 \\
\hline 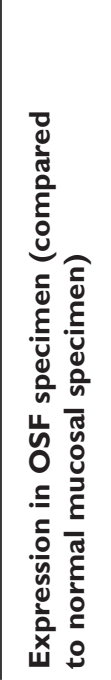 & 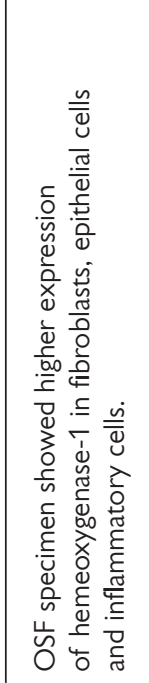 & 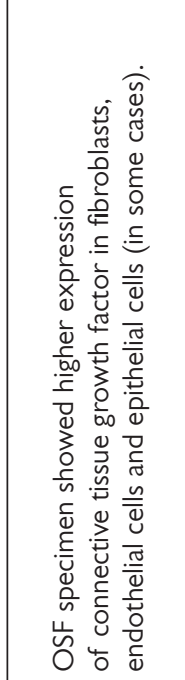 & 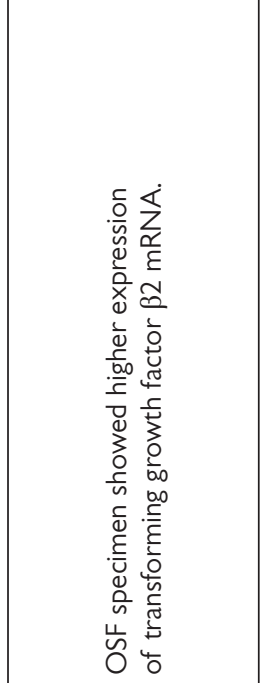 & 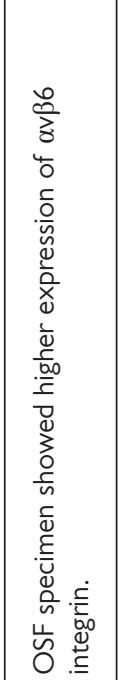 & 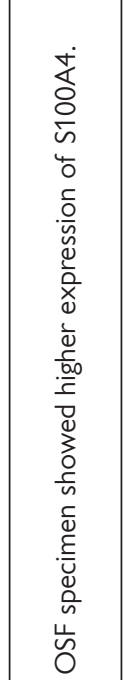 & 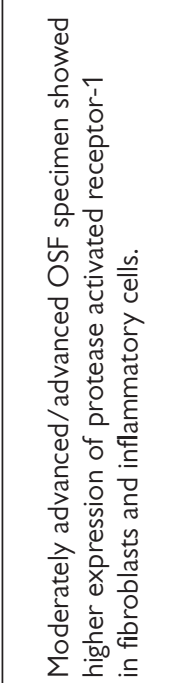 & 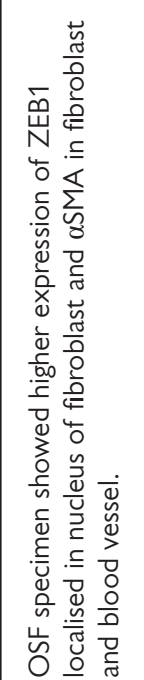 \\
\hline 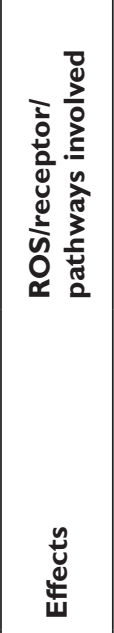 & 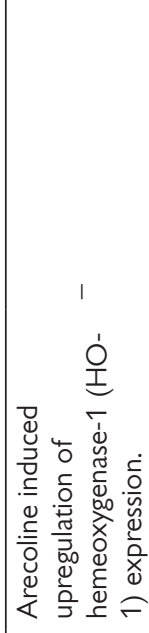 & 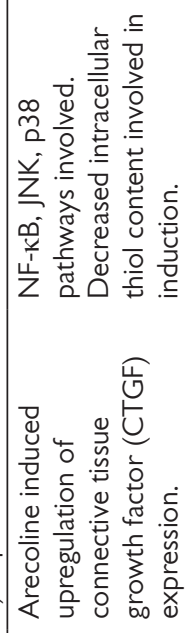 & 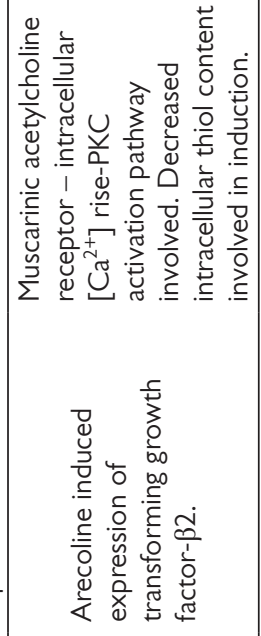 & 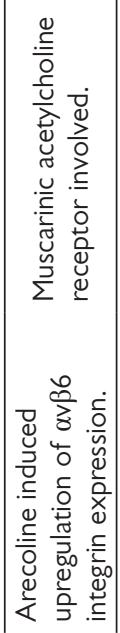 & 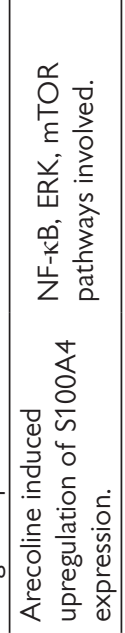 & 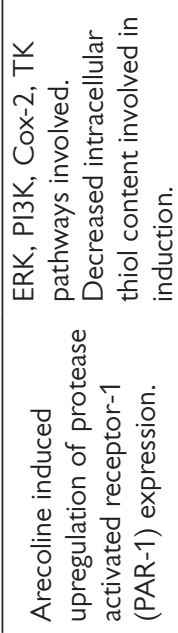 & 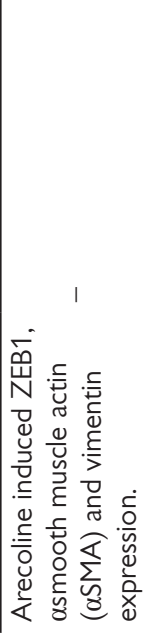 \\
\hline 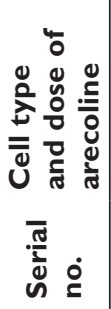 & 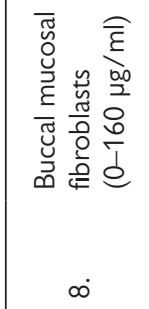 & 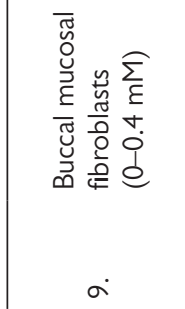 & 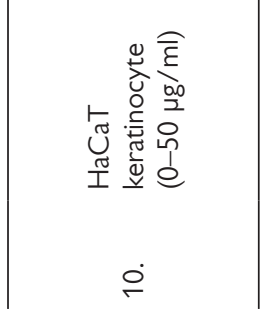 & 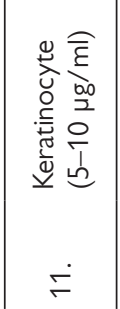 & 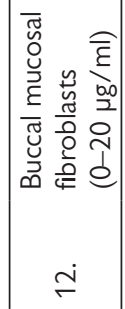 & 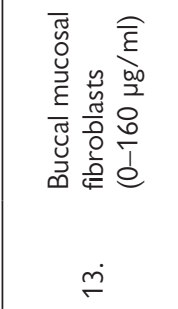 & 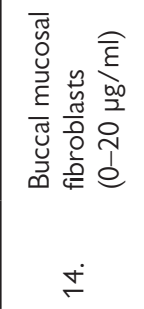 \\
\hline
\end{tabular}




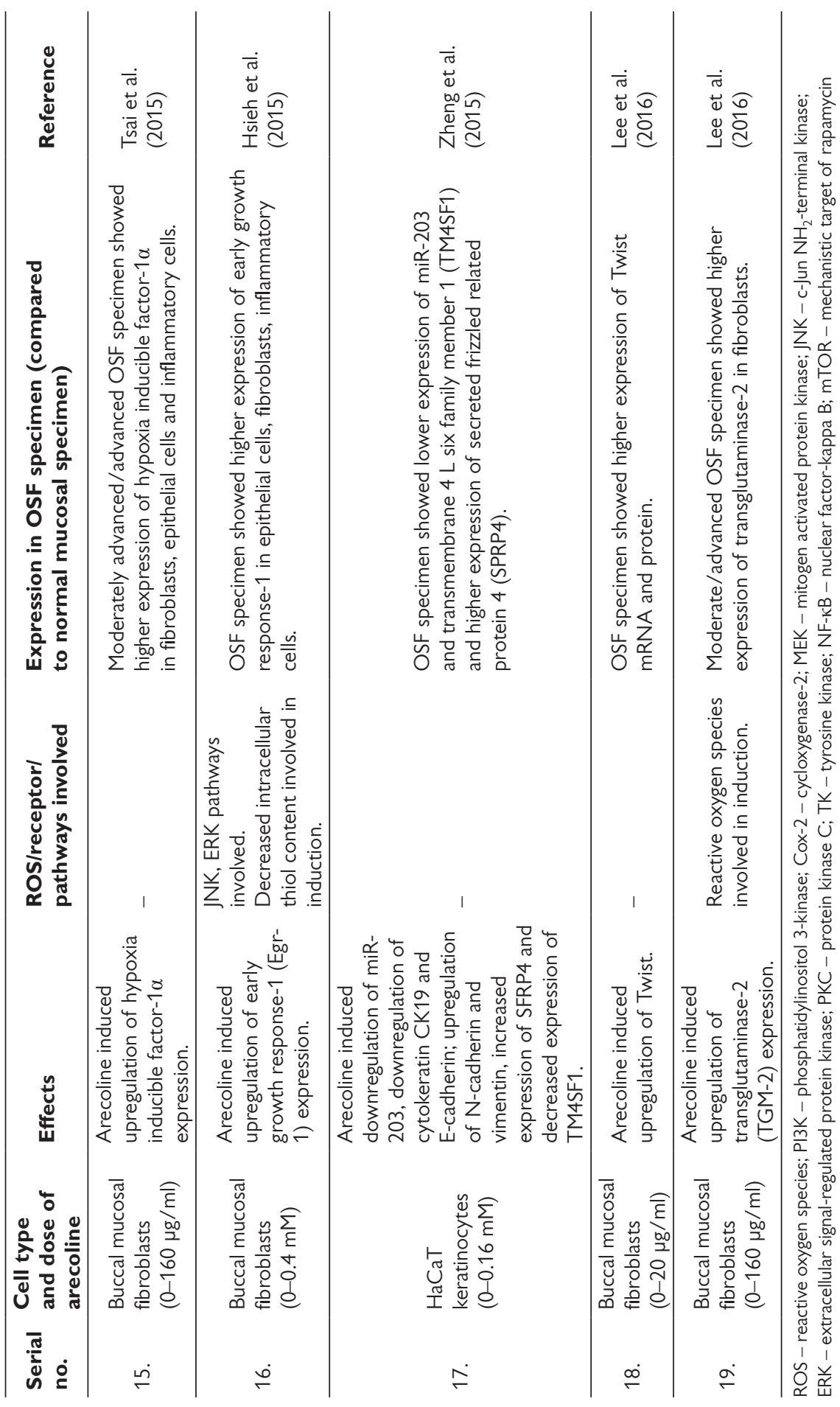


in turn triggers the myofibroblastic transformation of fibroblasts (Moutasim et al., 2011). After being activated via integrin, plasminogen activated receptor-1 (PAR-1) or TGM-2, TGF- $\beta 1$ binds to its receptor and sets on a cascade of signalling events that induce the expression of growth factors, cytokines and transcription factors in resident fibroblasts thereby transforming them into myofibroblasts (Figure 3) (Eickelberg et al., 1999; Griffin et al., 2002; Samarakoon et al., 2008; Lin et al., 2013; Yang et al., 2013, 2016; Chang et al., 2014; Lamouille et al., 2014; Chen et al., 2016; Hsieh et al., 2017). Myofibroblasts are cells specialized for wound healing with capacity for the secretion of ECM materials and cellular contraction (Micallef et al., 2012). TGF- $\beta 1$ stimulates myofibroblasts to produce modulators of ECM proteins (PAI-1, TIMP-1, CTGF, etc.) and transcription factors involved in epithelial-tomesenchymal transition (EMT) (Twist, Zeb, etc.) (Figure 3). Up-regulated expression of TGF- $\beta 1$ has also been observed in cancer tissue samples (Lu et al., 2004).

Another important mediator of arecoline induced effects is HIF-1 $\alpha$. Apart from being induced by arecoline itself in fibroblasts and epithelial cells (Lee et al., 2010; Tsai et al., 2015), it plays a part in the induction of several downstream factors that overlaps the repertoire induced by TGF- $\beta 1$ (Figure 3) (Higgins et al., 2004; Tsai and $\mathrm{Wu}, 2012)$. Hypoxia prevails in fibrotic as well as tumour conditions, which prevents degradation of HIF- $1 \alpha$. Under the hypoxic condition, stabilized HIF-1 $\alpha$ dimerizes with HIF-1 $\beta$ and, in association with co-activators, it participates in the transcription of genes with hypoxia-responsive element (HRE) (Tsai and Wu, 2012; Eckert et al., 2016; Rankin and Giaccia, 2016). As reviewed by Tsai and Wu (2012) and Rankin and Giaccia (2016), several genes involved in metastasiring are regulated by HIF-1 $\alpha$, including transcription factors involved in EMT (Twist, Snail, Aeb1/2, etc.), enzymes like matrix metalloproteinases (MMP 1/3), matricellular proteins (cysteine rich protein 61 [Cyr61]), and angiogenic factors (vascular endothelial growth factor).

Several of the pro-fibrotic or carcinogenic factors induced by arecoline are coupled with a decrease in intracellular thiol content and show reversible expression after treatment with antioxidants (Tables 1 and 2). This emphasizes ROS generation by arecoline to be a "cause" of the various arecoline driven "effects" that trigger OSF or OSCC. Interplay can be observed between ROS and TGF- $\beta 1$ as well as HIF-1 $\alpha$. For instance, ROS plays a part in the activation of latent TGF- $\beta 1$ complex tethered to the ECM (Jobling et al., 2006). In turn, TGF- $\beta 1$ acts to increase ROS production via the activity of its downstream target NADPH oxidase-4 (NOX-4) along with suppression of the antioxidant defence system of exposed cells (Richter and Kietzmann, 2016). Apart from sharing a common array of downstream targets, TGF- $\beta 1$ and HIF-1 $\alpha$ augment each other's expression too. HIF- $1 \alpha$ supports transcription of TGF- $\beta 1$ under hypoxic conditions, whereas, under normoxic conditions, TGF- $\beta 1$ enhances the stability of HIF-1 $\alpha$ by decreasing expression of HIF-1 $\alpha$ inhibitor prolyl hydroxylase 2 (PHD2) (McMohan et al., 2006; Hung et al., 2013). ROS induces HIF-1 $\alpha$ stability and thereby its transcriptional activity via an adenosine monophosphate-activated protein kinase (AMPK) pathway (Jung et al., 2008). 


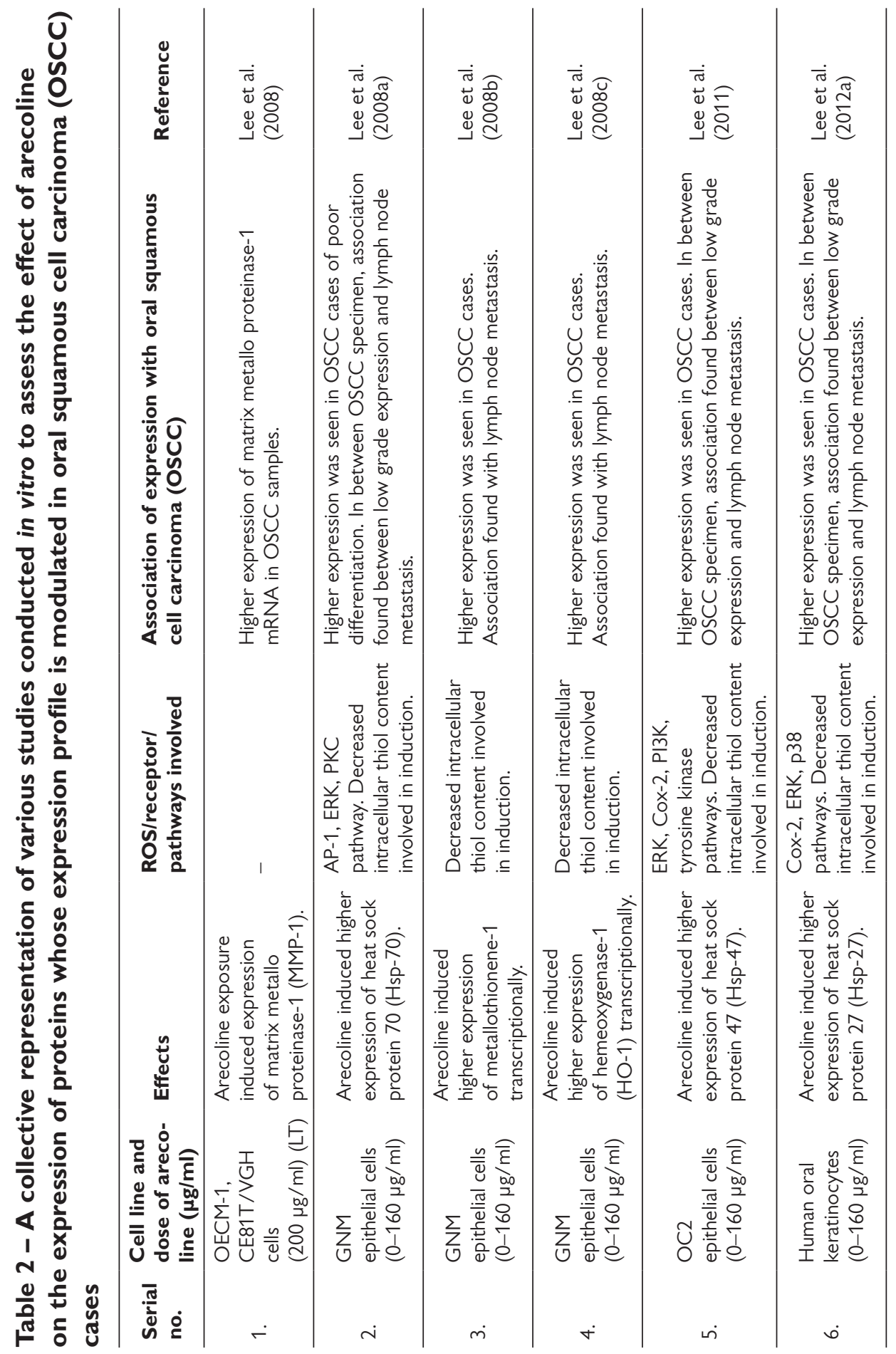




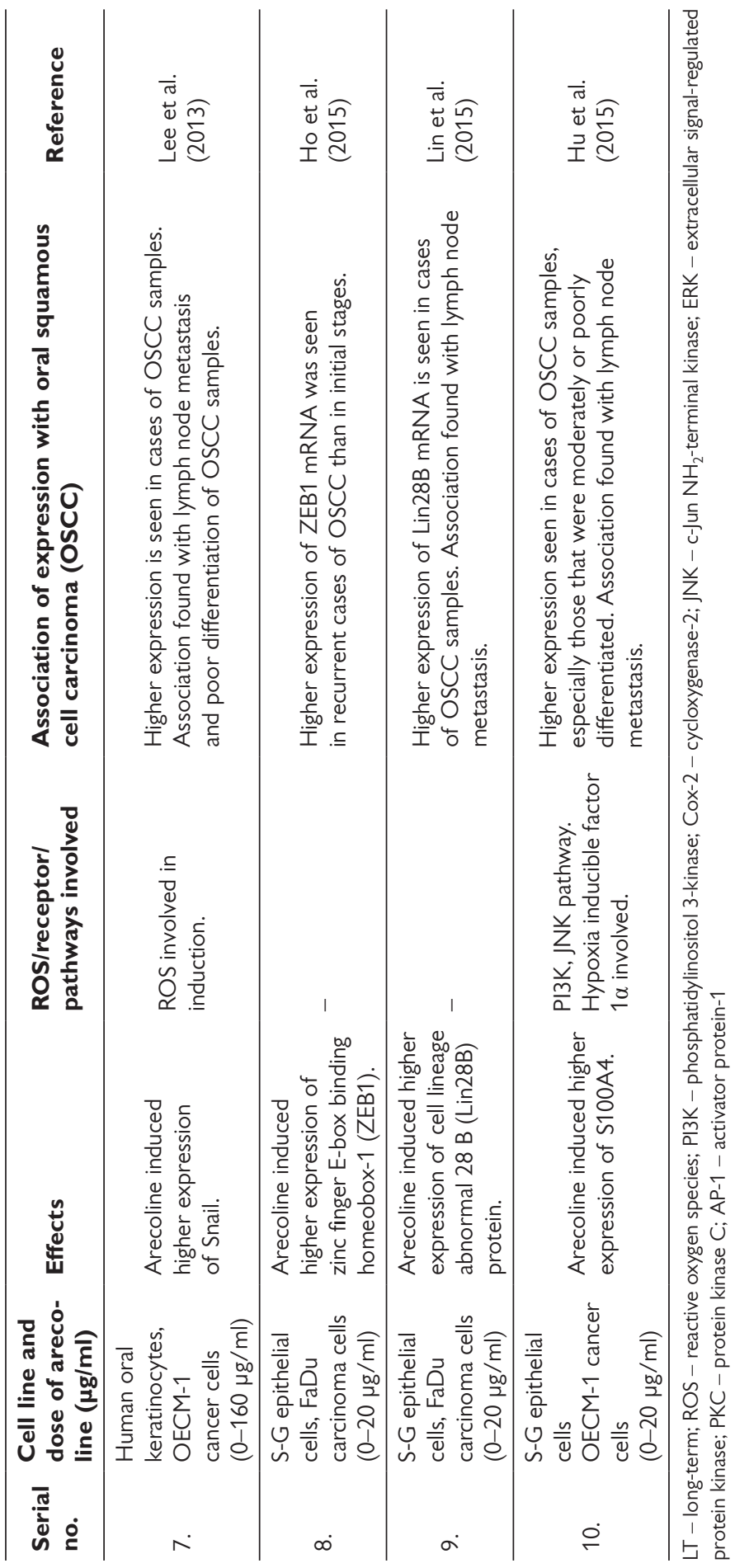




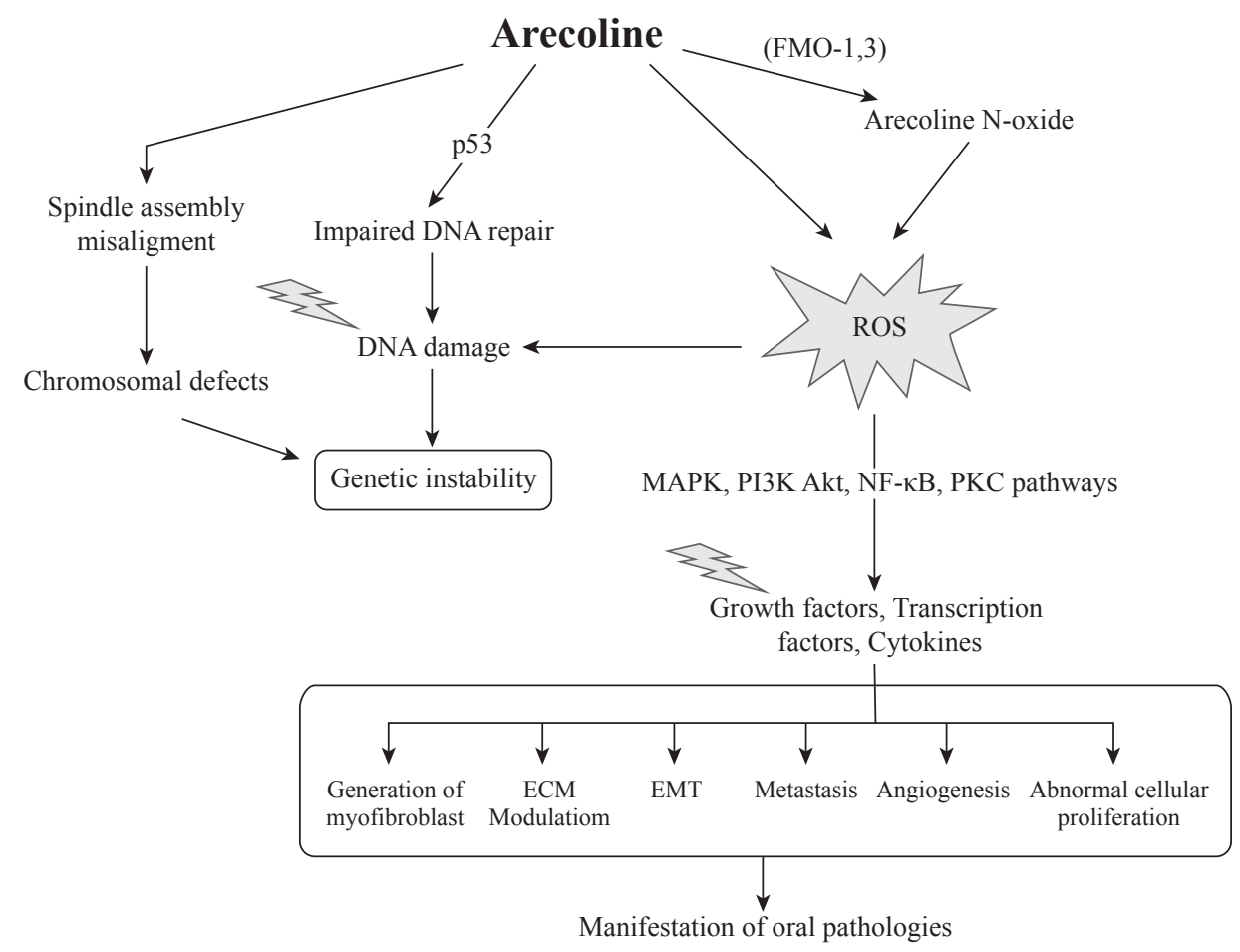

Figure 4 - A hypothetical mechanistic pathway of arecoline mediated oral pathologies. Induction indicated by the symbol: \&

ROS involvement in cancer includes induction of pathways like mitogen-activated protein kinase (MAPK), phosphatidylinositol-3-kinase (PI3K)/Akt and nuclear factor kappa-light chain enhancer of activated B-cells (NF-kB) (Liou and Storz, 2010). Analysis of the data compiled in Tables 1 and 2 also indicates these pathways to be involved in the up-regulation of pro-fibrotic or carcinogenic factors in cell systems affected by arecoline. Targeting these pathways might be a promising tool in the therapy of ROS induced OSF and OSCC.

Figure 4 depicts hypothetical mechanistic pathways where ROS induced DNA damage along with perturbation of expression profile of growth factors, transcription factors and ECM proteins drive the development of areca nut mediated oral pathologies.

As mentioned earlier, OSF can develop into a malignant phenotype. Therefore, it is important to understand how arecoline triggers the expression of effectors that mediate this transition. Under continuous exposure to hypoxic conditions and HIF-1 $\alpha$ activity, the transformation from fibrotic to cancer condition might take place, thereby highlighting arecoline's role as a tumour promoter. Arecoline induced stabilisation of HIF- $1 \alpha$ and activation of TGF- $\beta 1$ play roles in the regulation of 
several transcription factors, such as ZEB-1, Snail, Twist, that induce both type 1 and type 2 EMT leading to fibrosis and cancer, respectively (Lee et al., 2013; Chang et al., 2014; Ho et al., 2015; Lee et al., 2016).

Another interesting aspect of arecoline, which was discovered during the study, is its differential activity to induce ECM modulators in fibroblasts and cancer cells. Exposed fibroblasts up-regulate TIMP-1, whereas MMP-2 is inhibited (Chang et al., 2002a). In cancer cells, MMP-9 is induced, but TIMP-1 is inhibited (Chang et al., 2013a). TGF- $\beta 1$ has been found to regulate the expression of MMP-9 via Snail transcription factor in cancer cells (Sun et al., 2008). After exposure of cells from cancer cell line to arecoline for an extended period of time, increased expression of metalloproteinases MMP-8 and MMP-1 was observed (Liu et al., 2007; Lee et al., 2008). This might indicate that under already initiated and promoted tumour conditions, arecoline might play a role in the progression of areca nut induced carcinogenesis.

Junctional protein disruption is an essential phenomenon by which cells can acquire a metastatic phenotype (Parker et al., 2001). Giri et al. (2010) found arecoline to down-regulate tight junctional protein zona occludens-1 (ZO-1) and claudin-1 along with delocalisation of both ZO-1 and E-cadherin. Down-regulation of E-cadherin during junctional protein disruption leads to the dislocation of $\beta$-catenin from the plasma membrane. Under the influence of Wnt signalling in cancer conditions, degradation of cytoplasmic $\beta$-catenin is also inhibited. Both junctional and cytoplasmic $\beta$-catenin then moves to the nucleus and acquires transcriptional control over genes, leading to abnormal cell proliferative activity (Kam and Quaranta, 2009; Camilli and Weeraratna, 2010; Liu and Millar, 2010). Arecoline exposure induces elevated expression of $\beta$-catenin in epithelial cells (Lee et al., 2012b). Signalling cascades have been constructed using the accumulated data in Figure 3.

\section{Role of arecoline metabolites in areca nut induced oral pathologies}

Formation of these metabolites in vitro or in in vivo systems indicates the probability of exposure of humans to these metabolites. An assessment of the biological effects of these metabolites is, therefore, necessary to understand the areca nut mediated pathogenesis of OSF or OSCC.

The N-nitrosated metabolites, NMPA, NMPN and NGL, induce DNA single-stranded breaks in epithelial cells where NMPA was the strongest while NMPN and NGL were weak inducers (Sundqvist et al., 1989). Of the in vivo metabolites, genotoxic effects were displayed by arecaidine in mice via induction of sister chromatid exchanges (SCE) in bone marrow cells (Panigrahi and Rao, 1984). Arecoline $\mathrm{N}$-oxide was also found to be genotoxic in both mice model and fibroblasts (Kuo et al., 2015). The genotoxic potential of the other metabolites of arecoline is unknown.

Both MNPA and MNPN were found to be carcinogenic in rats (Wenke et al., 1984b; Nishikawa et al., 1992). NGL was neither found to be a strong mutagen in 
the bacterial test system nor a strong carcinogen in the murine test system (Rivenson et al., 1988; Miyazaki et al., 2005). Activated N-nitrosamines can cause alkylation of DNA base pairs (Miyazaki et al., 2005). Hence, activated areca nut derived nitrosamines can initiate carcinogenicity via alkylation of DNA, as indicated by the study where MNPN was observed to induce methylation and cyanoethylation of guanine residues in rats, especially in the genetic material obtained from nasal mucosa, esophagus and liver (Prokopczyk et al., 1987, 1988). The role of arecaidine as a profibrotic agent remains unclear as indicated by contradictory reports in in vitro models (Harvey et al., 1986; Tsai et al., 1999; Chang et al., 2013b).

The most important metabolite of arecoline might be arecoline $\mathrm{N}$-oxide. It was found to be mutagenic in bacteria without any metabolic activation (Lin et al., 2011). In mice, the compound induced increased collagen deposition in the tongue along with hyperplasia. Several pro-fibrotic genes (TGF- $\beta 1$, IL-6, S100A4, and fibronectin) were induced by the compound in fibroblasts along with suppression of E-cadherin (Kuo et al., 2015). Therefore, fibrosis induced by areca nut chewing can be mediated partially by arecoline $\mathrm{N}$-oxide. In another study, $\mathrm{N}$-oxide induced sub-lingual hyperplastic lesions in mice along with the up-regulated expression of caspase-8, which, instead of producing a pro-apoptotic effect, enhanced cell survival and proliferation (Ko et al., 2018). 8-hydroxydeoxy guanosine level in fibroblasts cultured in the presence of arecoline $\mathrm{N}$-oxide indicates oxidative stress induced DNA damage (Kuo et al., 2015). Similarly to arecoline, supplementation of thiol-containing agents can reverse the mutagenic property of the compound (Lin et al., 2011). These facts indicate oxidative stress to be an important factor for both arecoline and arecoline $\mathrm{N}$-oxide induced pathologies. Hence, the consumption of antioxidants can be a preventive factor against the development of fibrosis and areca nut driven oral cancer.

Table 3 summarizes the various effects of arecoline metabolites. It also provides an assessment of the potential harmfulness of the metabolites based on the possibility of involvement in areca nut induced pathologies. Although arecoline $\mathrm{N}$-oxide has been discovered as a possible candidate mediating areca nut effects, in the in vivo studies mentioned above, arecoline $\mathrm{N}$-oxide was administered via oral brushing. On the other hand, Lin et al. (2011) observed that the compound lost its mutagenicity after metabolic activation by 59 fraction of rat liver. Hence, the specific role of the compound in vivo remains uncertain because the knowledge about direct exposure through areca nut is still unknown.

\section{Involvement of enzymes in the metabolism of arecoline and arecoline N-oxide}

A study of arecoline metabolism along with metabolism of its metabolites arecaidine and arecoline $\mathrm{N}$-oxide has revealed basic routes that these compounds undergo. It involves de-esterification, $\mathrm{N}$-oxidation and reduction of the double bond leading to the formation of metabolites, including mercapturic acids, mercapturic acid derivatives and nipecotic acid derivatives (Nery, 1971; Giri et al., 2006, 2007). 
According to Patterson and Kosh (1993), cytochrome P450 (CYP450) family of enzymes do not play a significant role in arecoline metabolism because most of arecoline was metabolized by mice liver homogenate even in the presence of nonspecific CYP450 inhibitor. However, these enzymes might be involved in the metabolic activation of $\mathrm{N}$-nitrosamine compounds formed from arecoline. This is supported by a study conducted in a bacterial test system where metabolic activation of MNPN, MNPA and NGL was observed to be carried out by human CYP450 enzymes, especially by members of family CYP2A and CYP1A1 (Miyazaki et al., 2005). CYP enzymes activate $\mathrm{N}$-nitrosamines and the products formed, thereby lead to alkylation of nucleic acid base pairs (Miyazaki et al., 2005). Genetic polymorphisms of CYP enzyme encoding genes (CYP2A6 and CYP1A1) have been found to be associated with oral cancer (Kao et al., 2002; Topcu et al., 2002).

In contrast to CYP450, flavin-containing monooxygenases participate in the metabolism of arecoline to its $\mathrm{N}$-oxide (Giri et al., 2007). No association study has been found so far between the FMO polymorphism and oral cancer. As arecoline $\mathrm{N}$-oxide is biologically active and might have a prominent role in areca nut mediated fibrotic disorders, the existence of polymorphic variants of the gene encoding this enzyme in the general population might develop predisposition towards development of areca nut mediated fibrosis. FMO-1 carries out the process most efficiently of all the other isozymes (Giri et al., 2007). It is abundantly expressed in the kidney (Zhang and Cashman, 2006). An association has been found between betel quid chewing and chronic kidney disorder in a population-based study. However, the association was influenced by several other factors (Hsu et al., 2011). In addition, a portion of the formed $\mathrm{N}$-oxide undergoes reduction and forms the parent compound arecoline. CYP450 family of enzymes plays a role in this type of deoxygenation (Krueger and Williams, 2005; Montellano, 2013).

Carboxylesterases are involved in the metabolism of arecoline to arecaidine (Patterson and Kosh, 1993). In vitro, mercapturic acid formation from arecoline does not require any enzymatic assistance (Boyland and Nery, 1969). Therefore, under in vivo condition, mercapturic acid formation from the parent compound and metabolites might involve reaction with glutathione without the involvement of any enzymes. Although glutathione S-transferases (GSTs) participate in the phase 2 metabolism of xenobiotics, producing mercapturic acids (Hayakawa, 1977), the involvement of GSTs in arecoline metabolism is not known.

Apart from the study conducted by Patterson and Kosh (1993) and Giri et al. (2007), direct involvement of enzymes in the metabolism of arecoline in mammals has not been studied. In a study carried out by Chiang et al. (2007), arecoline has been found to suppress the expression of several phase I and phase II xenobiotic-metabolizing enzymes, which might indirectly affect the metabolism of arecoline itself. Moreover, mechanism of formation of other metabolites like nipecotic acid derivatives and the aldehyde derivative of arecoline (1-methyl3,4-dehydropiperidine-3-carboxaldehyde) has not been studied yet. 


\section{Table 3 - Summarizes the biological effects of the metabolites of arecoline}

\begin{tabular}{|c|c|c|c|}
\hline $\begin{array}{l}\text { Serial } \\
\text { no. }\end{array}$ & Metabolites & Biological activity & $\begin{array}{l}\text { Risk } \\
\text { assessment }\end{array}$ \\
\hline 1. & Arecaidine & $\begin{array}{l}\text { Mutagenic in bacterial tester strains } \\
\text { (TA100, TA 1535, TA 98, TA 1538) } \\
\text { (Shirname et al., 1983). } \\
\text { Induced sister chromatid exchange in } \\
\text { mice bone marrow cells (Panigrahi and } \\
\text { Rao, 1984). } \\
\text { Weakly induced DNA single strand } \\
\text { break in cultured human epithelial cells } \\
\text { (Sundqvist et al., 1989). } \\
\text { Induced both collagen formation by } \\
\text { fibroblasts and collagen phagocytic ability } \\
\text { reduction of fibroblasts (Harvey et al., } \\
\text { 1986; Tsai et al., 1999). } \\
\text { Had no effect on the myofibroblastic } \\
\text { transdifferentiation of fibroblasts } \\
\text { (Chang et al., 2013b). } \\
\text { Induced senescence, DNA double } \\
\text { stranded breaks along with } \\
\text { transforming growth factor- } \beta \text { and } \\
\text { matrix metalloproteinase-2 expressions } \\
\text { in fibroblasts (Rehman et al., 2016). }\end{array}$ & $\begin{array}{l}\text { Possibly } \\
\text { harmful }\end{array}$ \\
\hline
\end{tabular}

Mutagenic in bacterial tester strains (TA100, TA 98) (Lin et al., 2011). Induced DNA damage in both mammalian test system and cultured fibroblasts

2. Arecoline $\mathrm{N}$-oxide (Kuo et al., 2015). Induced pro-fibrotic genes in cultured

Possibly fibroblasts (Kuo et al., 2015). Induced caspase-8 activation which rather had a cell proliferative effect (Ko et al., 2018).

Induced tumour in several organ of exposed rats (Wenke et al., 1984b). Induced modification of DNA base pair

3. 3-methylnitrosaminoin exposed rats (Prokopczyk et al., propionitrile 1988; Rivenson et al., 1988). Weak inducer of DNA single strand breaks in cultured human epithelial cells (Sundqvist et al., 1989).

Induced DNA single strand break in cultured human epithelial cells

3-methylnitrosamino-
propionaldehyde
(Sundqvist et al., 1989). Induced tumour in several organ of Possibly exposed rats (Nishikawa et al., 1992). 


\begin{tabular}{|c|c|c|c|}
\hline $\begin{array}{l}\text { Serial } \\
\text { no. }\end{array}$ & Metabolites & Biological activity & $\begin{array}{l}\text { Risk } \\
\text { assessment }\end{array}$ \\
\hline 5. & $\mathrm{~N}$-nitrosoguvacoline & $\begin{array}{l}\text { Weakly carcinogenic in rats (Rivenson } \\
\text { et al., 1988). } \\
\text { Weak inducer of DNA single strand } \\
\text { breaks in cultured human epithelial cells } \\
\text { (Sundqvist et al., 1989). } \\
\text { Weakly mutagenic in bacterial tester } \\
\text { strains (TA100, TA 98) (Wang and Peng, } \\
\text { 1996). }\end{array}$ & $\begin{array}{l}\text { Possibly } \\
\text { harmless }\end{array}$ \\
\hline 6. & Arecaidine $\mathrm{N}$-oxide & Unknown & - \\
\hline 7. & $\mathrm{~N}$-methylnipecotic acid & Unknown & - \\
\hline 8. & $\begin{array}{l}\text { 1-methylnipecotic acid 1-oxide } \\
\text { methylester }\end{array}$ & Unknown & - \\
\hline 9. & $\begin{array}{l}\text { 1-methyl-3,4-dehydropiperidine- } \\
\text { 3-carboxaldehyde }\end{array}$ & Unknown & - \\
\hline 10. & Arecaidinylglycerol & Unknown & - \\
\hline 11. & Arecaidinylglycine & Unknown & - \\
\hline 12. & $\mathrm{~N}$-methylnipecotylglycine & Unknown & - \\
\hline 13. & Mercapturic acid of arecoline & Unknown & - \\
\hline 14. & Mercapturic acid of arecaidine & Unknown & - \\
\hline 15. & $\begin{array}{l}\text { Mercapturic acid of arecoline } \\
\mathrm{N} \text {-oxide }\end{array}$ & Unknown & - \\
\hline 16. & $\begin{array}{l}\text { 4-mercapto-1-methylnipecotic } \\
\text { acid methylester }\end{array}$ & Unknown & - \\
\hline 17. & $\begin{array}{l}\text { 4-methylmercapto-1- } \\
\text { methylnipecotic } \\
\text { acid 1-oxide methylester }\end{array}$ & Unknown & - \\
\hline 18. & $\mathrm{~N}$-nitrosonipecotic acid & Unknown & - \\
\hline
\end{tabular}

CYP450 and FMO mediated metabolism of arecoline $\mathrm{N}$-oxide has been found to take place in the mitochondria of liver cells in a study conducted by Wang et al. (2018). Mitochondrial metabolism of arecoline $\mathrm{N}$-oxide by the above-mentioned enzymes might be responsible for the generation of ROS, which mediates the toxic effects of the compound.

\section{Conclusion}

Apart from arecaidine and arecoline $\mathrm{N}$-oxide, the biological effects of other metabolites also need to be elucidated. Some of them might be promptly modified by enzymes in a manner similar to mercapturic acids so that their excretion is facilitated, and subsequently, they pose a lesser threat for carcinogenic activity. Other compounds as well as metabolites that possess a high toxic potential might 
also be present in areca nut and oral cells might be directly exposed to them on the consumption of the nut. For example, both arecaidine and $\mathrm{N}$-methylnipecotic acid are also present in areca nut (IARC Working Group on the Evaluation of Carcinogenic Risks to Humans, 2004; Hu et al., 2010). But as the toxicity of $\mathrm{N}$-methylnipecotic acid is not known, its effect on the site of exposure cannot be determined.

Knowledge about the enzymes and genes that encodes them can provide an important insight into the metabolism of these xenobiotics. This will open another field of research correlating the differential expression and polymorphisms of these genes to an individual predisposition to oral cancer in betel nut consumers. Even the metabolites might be more potent in causing hazardous effects than the parent compound, as seen in the case of arecoline $\mathrm{N}$-oxide.

\section{References}

Angadi, P. V., Kale, A. D., Hallikerimath, S. (2011) Evaluation of myofibroblasts in oral submucous fibrosis: correlation with disease severity. J. Oral Pathol. Med. 40, 208-213.

Boyland, E., Nery, R. (1969) Mercapturic acid formation during the metabolism of arecoline and arecaidine in rat. Biochem. J. 113, 123-130.

Boyland, E., Nice, E., Williams, K. (1971) The catalysis of nitrosation by thiocyanate from saliva. Food Cosmet. Toxicol. 9(5), 639-643.

Camilli, T. C., Weeraratna, A. T. (2010) Striking the target in Wnt-y conditions: Intervening in Wnt signalling during cancer progression. Biochem. Pharmacol. 80, 702-711.

Chang, M. C., Chan, C. P., Wang, W. T., Chang, B. E., Lee, J. J., Tseng, S. K., Yeung, S. Y., Hahn, L. J., Jeng, J. H. (2013a) Toxicity of areca nut ingredients: Activation of CHK1/CHK2, induction of cell cycle arrest, and regulation of MMP-9 and TIMPs production in SAS epithelial cells. Head Neck 35, 1295-1302.

Chang, M. C., Lin, L. D., Wu, H. L., Ho, Y. S., Hsien, H. C., Wang, T. M., Jeng, P. Y., Cheng, R. H., Hahn, L. J., Jeng, J. H. (2013b) Areca nut-induced buccal mucosa fibroblast contraction and its signalling: A potential role in oral submucous fibrosis - a precancer condition. Carcinogenesis 34, 1096-1104.

Chang, Y. C., Yang, S. F., Tai, K. W., Chou, M. Y., Hsieh, Y. S. (2002a) Increased tissue inhibitor of metalloproteinase-1 expression and inhibition of gelatinase A activity in buccal mucosal fibroblasts by arecoline as possible mechanisms for oral submucous fibrosis. Oral Oncol. 38, 195-200.

Chang, Y. C., Tsai, C. H., Tai, K. W., Yang, S. H., Chou, M. Y., Lii, C. K. (2002b) Elevated vimentin expression in buccal mucosal fibroblasts by arecoline in vitro as a possible pathogenesis for oral submucous fibrosis. Oral Oncol. 38, 425-430.

Chang, Y. C., Tsai, C. H., Lai, Y. L., Yu, C. C., Chi, W. Y., Li, J. J., Chang, W. W. (2014) Arecoline-induced myofibroblast transdifferentiation from human buccal mucosal fibroblasts is mediated by ZEB1. J. Cell. Mol. Med. 18, 698-708.

Chen, Y. C., Chen, B. C., Yu, C. C., Lin, S. H., Lin, C. H. (2016) miR-19a, -19b, and -26b mediate CTGF expression and pulmonary fibroblast differentiation. J. Cell. Physiol. 231, 2236-2248.

Chiang, S. L., Jiang, S. S., Wang, Y. J., Chiang, H. C., Chen, P. H., Tu, H. P., Ho, K. Y., Tsai, Y. S., Chang, I. S., Ko, Y. C. (2007) Characterization of arecoline-induced effects on cytotoxicity in normal human gingivial fibroblasts by global gene expression profiling. Toxicol. Sci. 100(1), 66-74.

Cox, S., Vickers, E. R., Ghu, S., Zoellner, H. (2010) Salivary arecoline levels during areca nut chewing in human volunteers. J. Oral Pathol. Med. 39, 465-469.

Das A.; Giri S. 
Dasgupta, R., Saha, I., Pal, S., Bhattacharyya, A., Sa, G., Nag, T. C., Das, T., Maiti, B. R. (2006) Immunosuppression, hepatotoxicity and depression of antioxidant status by arecoline in albino mice. Toxicology 227, 94-104.

Deb, S., Chatterjee, A. (1998) Influence of buthionine sulfoximine and reduced glutathione on arecolineinduced chromosomal damage and sister chromatid exchange in mouse bone marrow cells in vivo. Mutagenesis 13, 243-248.

Deng, Y. T., Chen, H. M., Cheng, S. J., Chiang, C. P., Kuo, M. Y. P. (2009) Arecoline-stimulated connective tissue growth factor production in human buccal mucosal fibroblasts: Modulation by curcumin. Oral Oncol. 45, e99-e105.

Eckert, A. W., Wickenhauser, C., Salins, P. C., Kappler, M., Bukur, J., Seliger, B. (2016) Clinical relevance of the tumor microenvironment and immune escape of oral squamous cell carcinoma. J. Transl. Med. 14, 85.

Eickelberg, O., Köhler, E., Reichenberger, F., Bertschin, S., Woodtli, T., Eme, P., Perruchoud, A. P., Roth, M. (1999) Extracellular matrix deposition by primary human lung fibroblasts in response to TGF-beta1 and TGF-beta3. Am. J. Physiol. 276(5), 814-824.

Ferlay, J., Soerjomataram, I., Dikshit, R., Eser, S., Mathers, C., Rebelo, M., Parkin, D. M., Forman, D., Bray, F. (2015) Cancer incidence and mortality worldwide: Sources, methods and major patterns in GLOBOCAN 2012. Int. J. Cancer 136, E359-E386.

Giri, S., Idle, J. R., Chen, C., Zabriskie, T. M., Krausz, K. W., Gonzalez, F. J. (2006) A metabolomic approach to the metabolism of the areca nut alkaloids arecoline and arecaidine in the mouse. Chem. Res. Toxicol. 19(6), 818-827.

Giri, S., Krausz, K. W., Idle, J. R., Gonzalez, F. J. (2007) The metabolomics of ( \pm )-arecoline 1-oxide in the mouse and its formation by human flavin-containing monooxygenases. Biochem. Pharmacol. 73(4), $561-573$.

Giri, S., Poindexter, K. M., Sundar, S. N., Firestone, G. L. (2010) Arecoline induced disruption of expression and localization of the tight junctional protein ZO-1 is dependent on the HER 2 expression in human endometrial Ishikawa cells. BMC Cell Biol. 11, 53.

Griffin, M., Casadio, R., Bergamini, C. M. (2002) Transglutaminases: Nature's biological glues. Biochem. J. 368, 377-396.

Harvey, W., Scutt, A., Meghji, S., Canniff, J. P. (1986) Stimulation of human buccal mucosa fibroblasts in vitro by betel-nut alkaloids. Arch. Oral Biol. 31(1), 45-49.

Hayakawa, T. (1977) Glutathione S-transferases in the metabolism of foreign compounds. Ecotoxicol. Environ. Saf. 1(3), 305-309.

Higgins, D. F., Biju, M. P., Akai, Y., Wutz, A., Johnson, R. S., Haase, V. H. (2004) Hypoxic induction of Ctgf is directly mediated by Hif-1. Am. J. Physiol. Renal Physiol. 287, 1223-1232.

Ho, C. M., Hu, F. W., Lee, S. S., Shieh, T. M., Yu, C. H., Lin, S. S., Yu, C. C. (2015) ZEB1 as an indicator of tumor recurrence for areca quid chewing-associated oral squamous cell carcinomas. J. Oral Pathol. Med.

44, 693-698.

Hsieh, Y. P., Chen, H. M., Chang, J. Z. C., Chiang, C. P., Deng, Y. T., Kuo, M. Y. P. (2015) Arecoline stimulated early growth response-1 production in human buccal fibroblasts: Suppression by epigallocatechin-3-gallate. Head Neck 37, 493-497.

Hsieh, Y. P., Chen, H. M., Lin, H. Y., Yang, H., Chang, J. Z. C. (2017) Epigallocatechin-3-gallate inhibits transforming-growth-factor- $\beta 1$-induced collagen synthesis by suppressing early growth response- 1 in human buccal mucosal fibroblasts. J. Formos. Med. Assoc. 116, 107-113.

Hsu, Y. H., Liu, W. H., Chen, W., Kuo, Y. C., Hsiao, C. Y., Hung, P. H., Jong, I. C., Chiang, P. C., Hsu, C. C. (2011) Association of betel nut chewing with chronic kidney disease: A retrospective 7-year study in Taiwan. Nephrology (Carlton) 16, 751-757. 
Hu, F. W., Lee, S. S., Yang, L. C., Tsai, C. H., Wang, T. H., Chou, M. Y., Yu, C. C. (2015) Knockdown of S100A4 impairs arecoline-induced invasiveness of oral squamous cell carcinomas. Oral Oncol. 51, 690-697.

Hu, W. C., Chang, Y. Z., Wang, H. W., Chao, M. R. (2010) High-throughput simultaneous analysis of five urinary metabolites of areca nut and tobacco alkaloids by isotope-dilution liquid chromatography-tandem mass spectrometry with on line solid phase extraction. Cancer Epidemiol. Biomarkers Prev. 19(10), 2570-2581.

Huang, L. W., Hsieh, B. S., Cheng, H. L., Hu, Y. C., Chang, W. T., Chang, K. L. (2012) Arecoline decreases interleukin- 6 production and induces apoptosis and cell cycle arrest in human basal cell carcinoma cells. Toxicol. Appl. Pharmacol. 258, 199-207.

Hung, S. P., Yang, M. H., Tseng, K. F., Lee, O. K. (2013) Hypoxia-induced secretion of TGF- $\beta 1$ in mesenchymal stem cell promotes breast cancer cell progression. Cell Transplant. 22, 1869-1882.

Hung, T. C., Huang, L. W., Su, S. J., Hsieh, B. S., Cheng, H. L., Hu, Y. C., Chen, Y. H., Hwang, C. C., Chang, K. L. (2011) Hemeoxygenase-1 expression in response to arecoline-induced oxidative stress in human umbilical vein endothelial cells. Int. J. Cardiol. 151, 187-194.

IARC Working Group on the Evaluation of Carcinogenic Risks to Humans (2004) Betel-quid and areca-nut chewing and some areca-nut-derived nitrosamines. IARC Monogr. Eval. Carcinog. Risks Hum. 85, 1-334.

Jeng, J. H., Wang, Y. J., Chiang, B. L., Lee, P. H., Chan, C. P., Ho, Y. S., Wang, T. M., Lee, J. J., Hahn, L. J., Chang, M. C. (2003) Roles of keratinocyte inflammation in oral cancer: Regulating the prostaglandin E2, interleukin- 6 and TNF- $\alpha$ production of oral epithelial cells by areca nut extract and arecoline. Carcinogenesis 24, 1301-1315.

Ji, W. T., Yang, S. R., Chen, J. Y. F., Cheng, Y. P., Lee, Y. R., Chiang, M. K., Chen, H. R. (2012) Arecoline downregulates levels of p21 and p27 through the reactive oxygen species/mTOR complex 1 pathway and may contribute to oral squamous cell carcinoma. Cancer Sci. 103, 1221-1229.

Jobling, M. F., Mott, J. D., Finnegan, M. T., Jurukovski, V., Erickson, A. C., Walian, P. J., Taylor, S. E., Ledbetter, S., Lawrence, C. M., Rifkin, D. B., Barcellos-Hof, M. H. (2006) Isoform-specific activation of latent transforming growth factor beta (LTGF-beta) by reactive oxygen species. Radat. Res. 166, 839-848.

Jung, S. N., Yang, W. K., Kim, J., Kim, H. S., Kim, E. J., Yun, H., Park, H., Kim, S. S., Choe, W., Kang, I., $\mathrm{Ha}$, J. (2008) Reactive oxygen species stabilize hypoxia-inducible factor-1 alpha protein and stimulate transcriptional activity via AMP-activated protein kinase in DU145 human prostate cancer cells.

Carcinogenesis 29(4), 713-721.

Kademani, D. (2007) Oral cancer. Mayo Clin. Proc. 82(7), 878-887.

Kao, S. Y., Wu, C. H., Lin, S. C., Yap, S. K., Chang, C. S., Wong, Y. K., Chi, L. Y., Liu, T. Y. (2002) Genetic polymorphism of cytochrome P4501A1 and susceptibility to oral squamous cell carcinoma and oral precancer lesions associated with smoking/betel use. J. Oral Pathol. Med. 31(9), 505-511.

Kam, Y., Quaranta, V. (2009) Cadherin-bound $\beta$-catenin feeds into the Wnt pathway upon adherens junction dissociation: Evidence for an intersection between $\beta$-catenin pools. PLoS One 4(2), e4580.

Kamath, V. V., Krishnamurthy, S., Satelur, K. P., Rajkumar, K. (2015) Transforming growth factor- $\beta 1$ and TGF- $\beta 2$ act synergistically in the fibrotic pathway in oral submucous fibrosis: An immunohistochemical observation. Indian J. Med. Paediatr. Oncol. 36(2), 111-116.

Ko, Y. C., Chang, P. Y., Kuo, T. M., Chen, P. K., Lin, Y. Z., Hua, C. H., Chen, Y. C. (2018) Arecoline N-oxide up-regulates caspase-8 expression in oral hyperplastic lesions of mice. J. Agric. Food Chem. 65(47), 10197-10205.

Krueger, S. K., Williams, D. E. (2005) Mammalian flavin containing monooxygenases: Structure/function, genetic polymorphisms and role in drug metabolism. Pharmacol. Ther. 106(3), 357-387.

Kuo, T. M., Luo, S. Y., Chiang, S. L., Yeh, K. T., Hsu, H. T., Wu, C. T., Lu, C. Y., Tsai, M. H., Chang, J. G.,

Das A.; Giri S. 
Ko, Y. C. (2015) Fibrotic effects of arecoline N-oxide in oral potentially malignant disorders. J. Agric. Food Chem. 63(24), 5787-5794.

Lamouille, S., Xu, J., Derynck, R. (2014) Molecular mechanisms of epithelial-mesenchymal transition. Nat. Rev. Mol. Cell Biol. 15, 178-196.

Lee, C. H., Liu, S. Y., Lin, M. H., Chiang, W. F., Chen, T. C., Huang, W. T., Chou, D. S., Chiu, C. T., Liu, Y. C. (2008) Upregulation of matrix metalloproteinase-1 (MMP-1) expression in oral carcinomas of betel quid (BQ) users: Roles of $\mathrm{BQ}$ ingredients in the acceleration of tumour cell motility through MMP-1. Arch. Oral Biol. 53, 810-818.

Lee, P. H., Chang, M. C., Chang, W. H., Wang, T. M., Wang, Y. J., Hahn, L. J., Ho, Y. S., Lin, C. Y., Jeng, J. H. (2006) Prolonged exposure to arecoline arrested human KB epithelial cell growth: Regulatory mechanisms of cell cycle and apoptosis. Toxicology 220, 81-89.

Lee, S. S., Tsai, C. H., Ho, Y. C., Chang, Y. C. (2008a) The upregulation of heat shock protein 70 expression in areca quid chewing-associated oral squamous cell carcinomas. Oral Oncol. 44, 884-890.

Lee, S. S., Yang, S. F., Ho, Y. C., Tsai, C. H., Chang, Y. C. (2008b) The upregulation of metallothionein-1 expression in areca quid chewing-associated oral squamous cell carcinomas. Oral Oncol. 44, 180-186.

Lee, S. S., Yang, S. F., Tsai, C. H., Chou, M. C., Chou, M. Y., Chang, Y. C. (2008c) Upregulation of heme oxygenase-1 expression in areca-quid-chewing-associated oral squamous cell carcinoma. J. Formos. Med. Assoc. 107, 355-363.

Lee, S. S., Tsai, C. H., Yang, S. F., Ho, Y. C., Chang, Y. C. (2010) Hypoxia inducible factor-1 $\alpha$ expression in areca quid chewing-associated oral squamous cell carcinomas. Oral Dis. 16, 696-701.

Lee, S. S., Tseng, L. H., Li, Y. C., Tsai, C. H., Chang, Y. C. (2011) Heat shock protein 47 expression in oral squamous cell carcinomas and up-regulated by arecoline in human oral epithelial cells. J. Oral Pathol. Med. 40, 390-396.

Lee, S. S., Tsai, C. H., Ho, Y. C., Yu, C. C., Chang, Y. C. (2012a) Heat shock protein 27 expression in areca quid chewing-associated oral squamous cell carcinomas. Oral Dis. 18, 713-719.

Lee, S. S., Tsai, C. H., Tsai, L. L., Chou, M. C., Chou, M. Y., Chang, Y. C. (2012b) $\beta$-catenin expression in areca quid chewing associated oral squamous cell carcinomas and up-regulated by arecoline in human oral epithelial cells. J. Formos. Med. Assoc. 111, 194-200.

Lee, S. S., Tsai, C. H., Yu, C. C., Chang, Y. C. (2013) Elevated snail expression mediates tumor progression in areca quid chewing-associated oral squamous cell carcinoma via reactive oxygen species. PLoS One $\mathbf{8}$, e67985.

Lee, S. S., Chen, Y. J., Tsai, C. H., Huang, F. M., Chang, Y. C. (2015) Elevated transglutaminase-2 expression mediates fibrosis in areca quid chewing-associated oral submucocal fibrosis via reactive oxygen species generation. Clin. Oral Investig. 20, 1029-1034.

Lee, Y. H., Yang, L. C., Hu, F. W., Peng, C. Y., Yu, C. H., Yu, C. C. (2016) Elevation of Twist expression by arecoline contributes to the pathogenesis of oral submucous fibrosis. J. Formos. Med. Assoc. 115, 311-317.

Lin, C. H., Yu, M. C., Tung, W. H., Chen, T. T., Yu, C. C., Weng, C. M., Tsai, Y. J., Bai, K. J., Hong, C. Y., Chien, M. H., Chen, B. C. (2013) Connective tissue growth factor induces collagen I expression in human lung fibroblasts through the Rac1/MLK3/JNK/AP-1 pathway. Biochim. Biophys. Acta 1833, 2823-2833.

Lin, K. H., Lin, C. Y., Liu, C. C., Chou, M. Y., Lin, J. K. (2011) Arecoline N-oxide: Its mutagenicity and possible role as ultimate carcinogen in areca oral carcinogenesis. J. Agric. Food Chem. 59(7), 3420-3428.

Lin, W. T., Shieh, T. M., Yang, L. C., Wang, T. Y., Chou, M. Y., Yu, C. C. (2015) Elevated Lin28B expression is correlated with lymph node metastasis in oral squamous cell carcinomas. J. Oral Pathol. Med. 44, 823-830.

Liou, G. Y., Storz, P. (2010) Reactive oxygen species in cancer. Free Radic. Res. 44(5), 479-496. 
Liu, F., Millar, S. E. (2010) Wnt/ $\beta$-catenin signaling in oral tissue development and disease. J. Dent. Res. 89, 318-330.

Liu, S. Y., Liu, Y. C., Huang, W. T., Huang, G. C., Chen, T. C., Lin, M. H. (2007) Up-regulation of matrix metalloproteinase- 8 by betel quid extract and arecoline and its role in 2D motility. Oral Oncol. 43 , 1026-1033.

Lu, S. L., Reh, D., Li, A. G., Woods, J., Corless, C. L., Martin, M. K., Wang, X. J. (2004) Overexpression of transforming growth factor-1 in head and neck epithelia results in inflammation, angiogenesis, and epithelial hyperproliferation. Cancer Res. 64, 4405-4410.

Marchei, E., Durgbanshi, A., Rossi, S., Garcia-Algar, O., Zuccaro, P., Pichini, S. (2005) Determination of arecoline (areca nut alkaloid) and nicotine in hair by high-performance liquid chromatography/ electrospray quadrupole mass spectrometry. Rapid Commun. Mass Spectrom. 19, 3416-3418.

McMohan, S., Charbonneau, M., Grandmont, S., Richard, D. E., Dubois, C. M. (2006) Transforming growth factor $\beta 1$ induces hypoxia-inducible factor-1 stabilization through selective inhibition of PHD2 expression. J. Biol. Chem. 281(34), 24171-24181.

Micallef, L., Vedrenne, N., Billet, F., Coulomb, B., Darby, I. A., Desmoulière, A. (2012) The myofibroblast, multiple origins for major roles in normal and pathological tissue repair. Fibrogenesis Tissue Repair 5, S5.

Miyazaki, M., Sugawara, E., Yoshimura, T., Yamazaki, H., Kamataki, T. (2005) Mutagenic activation of betel quid-specific $\mathrm{N}$-nitrosamines catalyzed by human cytochrome P450 coexpressed with NADPHcytochrome P450 reductase in Salmonella typhimurium YG7108. Mutat. Res. 581(1-2), 165-171.

Montellano, P. R. O. (2013) Cytochrome P-450-activated prodrugs. Future Med. Chem. 5(2), 213-228.

Moutasim, K. A., Jenei, V., Sapienza, K., Marsh, D., Weinreb, P. H., Violette, S. M., Lewis, M. P., Marshall, J. F., Fortune, F., Tilakratne, W. M., Hart, I. R., Thomas, G. J. (2011) Betel-derived alkaloid up-regulates keratinocyte alphavbeta6 integrin expression and promotes oral submucous fibrosis. J. Pathol. 223, 366-377.

Nery, R. (1971) The metabolic interconversion of arecoline and arecoline 1-oxide in the rat. Biochem. J. 122(4), 503-508.

Nishikawa, A., Prokopczyk, B., Rivenson, A., Zang, E., Hoffmann, D. (1992) A study of betel quid carcinogenesis. VIII. Carcinogenicity of 3-(methylnitrosamino)propionaldehyde in F344 rats. Carcinogenesis 13(3), 369-372.

Ohshima, H., Friesen, M., Bartsch, H. (1989) Identification in rats of N-nitrosonipecotic acid as a major urinary metabolite of the areca-nut alkaloid-derived nitrosamines, $\mathrm{N}$-nitrosoguvacoline and $\mathrm{N}$-nitrosoguvacine. Cancer Lett. 44(3), 211-216.

Panigrahi, G. B., Rao, A. R. (1984) Induction of in vivo sister chromatid exchanges byarecaidine, a betel nut alkaloid, in mouse bone marrow cells. Cancer Lett. 23(2), 189-192.

Parker, C., Rampaul, R. S., Pinder, S. E., Bell, J. A., Wencyk, P. M., Blamey, R. W., Nicholson, R. I., Robertson, J. F. R., Ellis, I. O. (2001) E-cadherin as a prognostic indicator in primary breast cancer. Br. J. Cancer $\mathbf{8 5}$, 1958-1963.

Patterson, T. A., Kosh, J. W. (1993) Elucidation of the rapid in vivo metabolism of arecoline. Gen. Pharmacol. 24(3), 641-647.

Pellegrini, M., Marchei, E., Rossi, S., Vagnarelli, F., Durgbanshi, A., Garcia-Algar, O., Vall, O., Pichini, S. (2007) Liquid chromatography/electrospray ionization tandem mass spectrometry assay for determination of nicotine and metabolites, caffeine and arecoline in breast milk. Rapid Commun. Mass Spectrom. 21, 2693-2703.

Peng, W., Liu, Y. J., Wu, N., Sun, T., He, X. Y., Gao, Y. X., Wu, C. J. (2015) Areca catechu L. (Arecaceae): A review of its traditional uses, botany, phytochemistry, pharmacology and toxicology. J. Ethnopharmacol. 164, 340-356. 
Pichini, S., Pellegrini, M., Pacifici, R., Marchei, E., Murillo, J., Puig, C., Vall, O., Garcia-Algar, O. (2003) Quantification of arecoline (areca nut alkaloid) in neonatal biological matrices by high-performance liquid chromatography/electrospray quadrupole mass spectrometry. Rapid Commun. Mass Spectrom. 17, 1958-1964.

Prokopczyk, B., Rivenson, A., Bertinato, P., Brunnemann, K. D., Hoffmann, D. (1987) 3-(Methylnitrosamino) proprionitrile: Occurrence in saliva of betel quid chewers, carcinogenicity, and DNA methylation in F344 rats. Cancer Res. 47(2), 467-471.

Prokopczyk, B., Bertinato, P., Hoffmann, D. (1988) Cyanoethylation of DNA in vivo by 3-(methylnitrosamino) propionitrile, an Areca-derived carcinogen. Cancer Res. 48(23), 6780-6784.

Rankin, E. B., Giaccia, A. J. (2016) Hypoxic control of metastasis. Science 352, 175-180.

Rehman, A., Ali, S., Lone, M. A., Atif, M., Hassona, Y., Prime, S. S., Pitiyage, G. N., James, E. L. N., Parkinson, E. K. (2016) Areca nut alkaloids induce irreparable DNA damage and senescence in fibroblasts and may create a favourable environment for tumour progression. J. Oral Pathol. Med. 45(5), 365-372.

Reichart, P. A., Philipsen, H. P. (2005) Oral erythroplakia - a review. Oral Oncol. 41, 551-561.

Richter, K., Kietzmann, T. (2016) Reactive oxygen species and fibrosis: further evidence of a significant liason. Cell Tissue Res. 365, 591-605.

Rivenson, A., Hoffmann, D., Prokopczyk, B., Amin, S., Hecht, S. S. (1988) Induction of lung and exocrine pancreas tumours in F344 rats by tobacco-specific and Areca-derived N-nitrosamines. Cancer Res. 48(23), 6912-6917.

Rivera, C. (2015) Essentials of oral cancer. Int. J. Clin. Exp. Pathol. 8, 11884-11894.

Samarakoon, R., Higgins, S. P., Higgins, C. E., Higgins, P. J. (2008) TGF- $\beta 1$-induced plasminogen activator inhibitor-1 expression in vascular smooth muscle cells requires pp60(c-src)/EGFR(Y845) and Rho/ROCK signalling. J. Mol. Cell. Cardiol. 44, 527-538.

Shieh, D. H., Chiang, L. C., Lee, C. H., Yang, Y. H., Shieh, T. Y. (2004) Effects of arecoline, safrole, and nicotine on collagen phagocytosis by human buccal mucosal fibroblasts as a possible mechanism for oral submucous fibrosis in Taiwan. J. Oral Pathol. Med. 33, 581-587.

Shirname, L. P., Menon, M. M., Nair, J., Bhide, S. V. (1983) Correlation of mutagenicity and tumorigenicity of betel quid and its ingredients. Nutr. Cancer 5(2), 87-91.

Shirname, L. P., Menon, M. M., Bhide, S. V. (1984) Mutagenicity of betel quid and its ingredients using mammalian test systems. Carcinogenesis 5, 501-503.

Shivapurkar, N. M., D'Souza, A. V., Bhide, S. V. (1980) Effect of betel-quid chewing on nitrite levels in saliva. Food Cosmet. Toxicol. 18(3), 277-281.

Sun, L., Diamond, M. E., Ottaviano, A. J., Joseph, M. J., Ananthanarayan, V., Hidayatullah G., Munshi, H. G. (2008) Transforming growth factor- $\beta 1$ promotes matrix metalloproteinase-9 mediated oral cancer invasion through snail expression. Mol. Cancer Res. 6(1), 10-20.

Sundqvist, K., Liu, Y., Nair, J., Bartsch, H., Arvidson, K., Grafström, R. C. (1989) Cytotoxic and genotoxic effects of areca nut-related compound in cultured human buccal epithelial cells. Cancer Res. 49, 5294-5298.

Thangjam, G. S., Kondaiah, P. (2009) Regulation of oxidative-stress responsive genes by arecoline in human keratinocytes. J. Periodontal Res. 44, 673-682.

Thangjam, G. S., Agarwal, P., Balapure, A. K., Rao, S. G., Kondaiah, P. (2009) Regulation of extracellular matrix genes by arecoline in primary gingival fibroblasts requires epithelial factors. J. Periodontal Res. 44, 736-743.

Tilakaratne, W. M., Klinikowski, M. F., Saku, T., Peters, T. J., Warnakuasuriya, S. (2006) Oral submucous fibrosis: review on aetiology and pathogenesis. Oral Oncol. 42, 561-568.

Topcu, Z., Chiba, I., Fujieda, M., Shibata, T., Ariyoshi, N., Yamazaki, H., Sevqican, F., Muthumala, M., 
Kobayashi, H., Kamataki, T. (2002) CYP2A6 gene deletion reduces oral cancer risk in betel quid chewers in Sri Lanka. Carcinogenesis 23(4), 595-598.

Tsai, C. C., Ma, R. H., Shieh, T. Y. (1999) Deficiency in collagen and fibronectin phagocytosis by human buccal mucosa fibroblasts in vitro as a possible mechanism for oral submucous fibrosis. J. Oral Pathol. Med. 28(2), 59-63.

Tsai, C. H., Chou, M. Y., Chang, Y. C. (2003) The up-regulation of cyclooxygenase-2 expression in human buccal mucosal fibroblasts by arecoline: A possible role in the pathogenesis of oral submucous fibrosis. J. Oral Pathol. Med. 32, 146-153.

Tsai, C. H., Yang, S. F., Chen, Y. J., Chou, M. Y., Chang, Y. C. (2005a) The upregulation of insulin-like growth factor-1 in oral submucous fibrosis. Oral Oncol. 41, 940-946.

Tsai, C. H., Yang, S. F., Chen, Y. J., Chou, M. Y., Chang, Y. C. (2005b) Raised keratinocyte growth factor-1 expression in oral submucous fibrosis in vivo and up-regulated by arecoline in human buccal mucosal fibroblasts in vitro. J. Oral Pathol. Med. 34, 100-105.

Tsai, C. H., Yang, S. F., Chang, Y. C. (2007) The upregulation of cystatin C in oral submucous fibrosis. Oral Oncol. 43, 680-685.

Tsai, C. H., Yang, S. F., Lee, S. S., Chang, Y. C. (2009) Augmented heme oxygenase-1 expression in areca quid chewing-associated oral submucous fibrosis. Oral Dis. 15, 281-286.

Tsai, C. H., Lee, S. S., Huang, F. M., Chang, Y. C. (2013) Regulation of protease-activated receptor-1 expression in human buccal fibroblasts stimulated with arecoline. Head Neck 35, 1314-1318.

Tsai, C. H., Lee, S. S., Chang, Y. C. (2015) Hypoxic regulation of plasminogen activator inhibitor-1 expression in human buccal mucosa fibroblasts stimulated with arecoline. J. Oral Pathol. Med. 44, 669-673.

Tsai, Y. P., Wu, K. J. (2012) Hypoxia-regulated target genes implicated in tumor metastasis. J. Biomed. Sci. 19, 102.

Tsai, Y. S., Lee, K. W., Huang, J. L., Liu, Y. S., Juo, S. H. H., Kuo, W. R., Chang, J. G., Lin, C. S., Jong, Y. J. (2008) Arecoline, a major alkaloid of areca nut, inhibits $p 53$, represses DNA repair, and triggers DNA damage response in human epithelial cells. Toxicology 249, 230-237.

Wang, C. K., Peng, C. H. (1996) The mutagenicities of alkaloids and N-nitrosoguvacoline from betel quid. Mutat. Res. 360, 165-171.

Wang, T. S., Lin, C. P., Chen, Y. P., Chao, M. R., Li, C. C., Liu, K. L. (2018) CYP450-mediated mitochondrial ROS production involved in arecoline $\mathrm{N}$-oxide-induced oxidative damage in liver cell lines. Environ. Toxicol. 33, 1029-1038.

Wang, Y. C., Tsai, Y. S., Huang, J. L., Lee, K. W., Kuo, C. C., Wang, C. S., Huang, A. M., Chang, J. Y., Jong, Y. J., Lin, C. S. (2010) Arecoline arrests cells at prometaphase by deregulating mitotic spindle assembly and spindle assembly checkpoint: Implication for carcinogenesis. Oral Oncol. 46, 255-262.

Wen, X. M., Zhang, Y. L., Liu, X. M., Guo, S. X., Wang, H. (2006) Immune responses in mice to arecoline mediated by lymphocyte muscarinic acetylcholine receptor. Cell Biol. Int. 30, 1048-1053.

Wenke, G., Hoffmann, D. (1983) A study of betel quid carcinogenesis. I. On the in vitro N-nitrosation of arecoline. Carcinogenesis 4(2), 169-172.

Wenke, G., Brunnemann, K. D., Hoffmann, D., Bhide, S. V. (1984a) A study of betel quid carcinogenesis. IV. Analysis of the saliva of betel chewers: a preliminary report. J. Cancer Res. Clin. Oncol. 108(1), 110-113.

Wenke, G., Rivenson, A., Hoffmann, D. (1984b) A study of betel quid carcinogenesis. 3. 3-(Methylnitrosamino)-propionitrile, a powerful carcinogen in F344 rats. Carcinogenesis 5(9), 1137-1140.

Wu, I. C., Chen, P. H., Wang, C. J., Wu, D. C., Tsai, S. M., Chao, M. R., Chen, B. H., Lee, H. H., Lee, C. H., Ko, Y. C. (2010) Quantification of blood betel quid alkaloids and urinary 8-hydroxydeoxyguanosine in humans and their association with betel chewing habits. J. Anal. Toxicol. 34, 325-331.

Yang, S. F., Hsieh, Y. S., Tsai, C. H., Chou, M. Y., Chang, Y. C. (2003) The upregulation of type I plasminogen activator inhibitor in oral submucous fibrosis. Oral Oncol. 39, 367-372.

Das A.; Giri S. 
Yang, S. F., Tsai, C. H., Chang, Y. C. (2008) The upregulation of heat shock protein 47 expression in human buccal fibroblasts stimulated with arecoline. J. Oral Pathol. Med. 37, 206-210.

Yang, W. H., Kuo, M. Y., Liu, C. M., Deng, Y. T., Chang, H. H., Chang, J. Z. (2013) Curcumin inhibits TGFB1-induced CCN2 via Src, JNK, and Smad3 in gingiva. J. Dent. Res. 92, 629-634.

Yang, W. H., Deng, Y. T., Hsieh, Y. P., Wu, K. J., Kuo, M. Y. (2016) Thrombin activates latent TGFß1 via integrin $\alpha v \beta 1$ in gingival fibroblasts. J. Dent. Res. 95, 939-945.

Yu, C. C., Tsai, C. H., Hsu, H. I., Chang, Y. C. (2013) Elevation of S100A4 expression in buccal mucosal fibroblasts by arecoline: Involvement in the pathogenesis of oral submucous fibrosis. PLoS One 8, e55122.

Zhang, J., Cashman, J. R. (2006) Quantitative analysis of FMO gene mRNA levels in human tissues. Drug Metab. Dispos. 34, 19-26.

Zheng, L., Jian, X., Guo, F., Li, N., Jiang, C., Yin, P., Min, A. J., Huang, L. (2015) miR-203 inhibits arecolineinduced epithelial-mesenchymal transition by regulating secreted frizzled-related protein 4 and transmembrane-4 L six family member 1 in oral submucous fibrosis. Oncol. Rep. 33, 2753-2760.

Zhou, Z. S., Li, M., Gao, F., Peng, J. Y., Xiao, H. B., Dai, L. X., Lin, S. R., Zhang, R., Jin, L. Y. (2013) Arecoline suppresses $\mathrm{HaCaT}$ cell proliferation through cell cycle regulatory molecules. Oncol. Rep. 29, 2438-2444. 